\title{
MENINGKATKAN KONSENTRASI ANAK DENGAN KEGIATAN MENGANYAM KAIN PERCA PADA ANAK USIA 5-6 TAHUN DI TK TUNAS MUDA KERSIK KEC.MARARANGKAYU KAB. KUTAI KARTANEGARA
}

\author{
Hasnawati \\ PG PAUD, FKIP, Universitas Widya Gama Mahakam Samarinda \\ ( hasnawati746@yahoo.com) \\ Mahkamah Brantasari \\ PG PAUD, FKIP, Universitas Widya Gama Mahakam Samarinda \\ (brantasari@gmail.com)
}

\begin{abstract}
Concentration is how the child focuses on doing things so that the work can be done within a certain time. While weaving is arranged to sort the arranged sheets in the form of bamboo, paper, rattan, animal skin, or patchwork. This research is motivated by children on 5-6 years old who are still low concentration, especially on children's concentration skills and learning activities is limited to the children's work sheet. In this study the authors propose the problem formulation is whether the weaving patchwork activities can improve the concentration of children on 5-6 years old in Tunas Muda Kindergarten, Kersik Village, Marangkayu District - Kutai Kartanegara. This research used Class Action Research (PTK) in a participative collaborative that aims to improve the concentration of children through patchy weaving activities on children 5-6 years old in Tunas Muda Kindergarten, Kersik Village, Marangkayu District - Kutai Kartanegara. The subjects in this study are 8 children, consisting of 4 men and 4 women. The Object in this study is to increase the concentration of children through weaving patchwork activities. The method used in data collection in this study is observation and documentation, while the techniques and data analysis using qualitative and quantitative descriptive analysis techniques. The results can be seen from the observation of the development in each cycle that in the first cycle average of good value only by $79 \%$ and in the second cycle average of $87 \%$ with an increase of $8 \%$ so that the percentage increase in the concentration of children through children weaving patchwork activities exceed indicator of success is good. It can be concluded that with patchwork weaving activities can increase the concentration of children on 5-6 years old in Tunas Muda Kindergarten, Kersik Village, Marangkayu District Kutai Kartanegara, year of academic 2017/2018.
\end{abstract}

Keywords: Concentration, Weaving, Children on 5-6 years old

\section{PENDAHULUAN}

Anak usia dini adalah sosok individu yang sedang menjalani suatu proses perkembangan dengan pesat dan fundamental bagi kehidupan anak selanjutnya. Anak usia dini berada pada rentang usia 0-8 tahun. Pada masa ini proses pertumbuhan dan perkembangan dalam berbagai aspek sedang mengalami masa yang cepat dalam rentang perkembangan hidup manusia. Proses pembelajaran sebagai bentuk perlakuan yang diberikan pada anak harus memperhatikan karakteristik yang dimiliki setiap tahapan perkembangan anak. 
Jurnal Warna : Jurnal Pendidikan Dan Pembelajaran Anak Usia dini. September 2017. Vol 02. No. 02

Menganyam dalam arti pendidikan berarti mengatur bilah atau lembaran lembaran yang diatur tersebut berupa bambu, daun, janur, kertas, rotan, kulit binatang atau kaing perca. merupakan salah satu hasil kerajinan masyarakat Indonesia. Banyak benda yang dihasilkan dari menganyam. Dari perlengkapan rumah tangga sampai pada properti interior ruangan. Masyarakat semakin banyak menggunakan teknik anyaman sebagai pelengkap kebutuhan. Hal ini tidak mengherankan karena di Indonesia, terdapat banyak tumbuhtumbuhan yang dapat digunakan sebagai bahan untuk menganyam. Beberapa tanaman yang sangat baik digunakan sebagai bahan menganyam adalah bambu, pandan,daun, rotan, paku-pakis, dan lidi. Semua bahan tersebut harus melewati beberapa proses agar dapat menjadi bahan jadi, yang siap untuk dianyam. Istilah dalam menganyam terbagi 2, yaitu lusi dan pakan. Lusi adalah iratan yang sudah diatur sedangkan pakan adalah iratan yang akan dianyam.

Menganyam untuk anak usia 5-6 tahun tidak dilakukan dengan teknik yang komplek, namun masih dalam tahap teknik dasar menganyam sederhana. Menganyam diajarkan dengan sangat sederhana kepada anak. Kemampuan menganyam dapat mengasah keterampilan motorik halus anak karena menggunakan tangan dan jari-jari demikian juga dengan kordinasi mata. Selain keterampilan motorik halus yang dikembangkan, menganyam juga dapat digunakan sebagai alat untuk melatih logika anak, belajar matematika, dan melatih konsentrasi.

Masa lima tahun pertama pertumbuhan dan perkembangan anak sering disebut sebagai masa keemasan, karena pada masa itu keadaan fisik maupun segala kemampuan anak sedang berkembang cepat. Dalam mengembangkan kemampuan motoriknya, anak juga mengembangkan kemampuan mengamati, mengingat hasil pengamatannya dan pengalamannya. Pendidikan anak usia dini merupakan salah satu bentuk penyelenggaraan pendidikan yang menitik beratkan pada peletakan dasar ke arah pertumbuhan dan perkembangan fisik (koordinasi motorik halus dan motorik kasar), kecerdasan (daya pikir, daya cipta, kecerdasan emosi, kecerdasan spiritual), sosial emosional (sikap dan perilaku serta beragama), bahasa dan komunikasi, sesuai dengan keunikan dan tahap-tahap perkembangan yang dilalui oleh anak usia dini. Dalam hal ini peran guru sangat menentukan tercapainya tujuan pendidikan tersebut. Sehingga guru TK dituntut dalam pembelajarannya untuk menggunakan metode yang sesuai 
Jurnal Warna : Jurnal Pendidikan Dan Pembelajaran Anak Usia dini. September 2017. Vol 02. No. 02

dengan tingkat perkembangan anak serta alat peraga dan bahan ajar yang menunjang anak untuk bisa memahami materi kegiatan.

Apabila anak mau menyelesaikan sendiri anyamannya, maka hasilnya kurang maksimal atau kurang tepat. Selama ini guru lebih sering mengembangkan kemampuan motorik halus anak dalam hal menulis, mengambar, dan mewarnai. keterampilan motorik halus yang lain seperti melipat, menjahit, menganyam jarang diberikan oleh guru. Pada saat guru memberikan kegiatan yang dapat mengembangkan kemampuan motorik halus anak, guru lebih sering menggunakan metode pemberian tugas dan jarang dilakukan melalui kegiatan bermain. Hal ini kurang menarik bagi anak, sehingga keterampilan menganyam anak kurang berkembangan dengan maksimal. Berkaitan dengan hal tersebut bahwa mulai awal semester genap 2017/2018 penulis mengamati terhadap anak tentang bidang meningkatkan konsentrasi anak dengan kegiatan menganyam kain perca menjadi bentuk sederhana yang hasilnya belum maksimal. Sebab menganyam merupakan salah satu dari pengembangan motorik halus anak.

Pada prinsipnya keterampilan menganyam yang dilakukan oleh anak merupakan kegiatan yang membutuhkan ketelitian, kejelian, dan kesabaran. Tujuan penelitian ini adalah untuk Meningkatkan konsentrasi anak dengan kegiatan menganyam kain perca pada anak usia 5-6 tahun di Tk. Tunas Muda Kersik.

Kegiatan bermain di TK Tunas Muda Kersik, kemampuan konsentrasi anak dengan kegiatan menganyam kain perca pada anak usia 5-6 tahun belum begitu berkembang. Anak usia 5-6 tahun di TK Tunas Muda Kersik berjumlah 8 anak. Masih banyak anak yang mengalami keterlambatan dalam kegiatan menganyam kain perca. Dalam kegiatan menganyam kain perca masih banyak anak yang belum mampu menganyam dengan benar. Selain itu masih banyak pula anak yang menganyam tidak tepat pada tempat kosong yang telah disediakan. Faktor penghambat dalam kegiatan tersebut bisa disebabkan oleh para orang tua ataupun guru yang sering kali mengabaikan pengembangan keterampilan menganyam kain perca pada anak. Faktor penyebab lainnya adalah lemahnya koordinasi mata dan otot-otot tangan. Selain itu bisa disebabkan karena guru belum menggunakan media lain yang lebih variatif sehingga anak kurang tertarik. Hal ini bisa mengakibatkan kurang optimalnya konsentrasi anak dengan kegiatan menganyam kain perca. 
Jurnal Warna : Jurnal Pendidikan Dan Pembelajaran Anak Usia dini. September 2017. Vol 02. No. 02

Permasalahan di atas harus dipecahkan.

Tentunya harus ada solusi yang tepat untuk menangani permasalahan tersebut.

Untuk itulah peneliti bermaksud memecahkan masalah tersebut melalui Penelitian Tindakan Kelas dengan judul "Meningkatkan Konsentrasi anak dengan kegiatan menganyam kain perca usia 5-6 tahun di TK Tunas Muda Kersik Kec. Marangkayu Kab. Kutai Kartanegara".

\section{METODOLOGI PENELITIAN}

\section{Pendekatan dan Jenis Penelitian}

Pendekatan yang digunakan dalam penelitian ini adalah pendekatan kualitatif, penelitian ini berangkat dari masalah yang didapat dilapangan, kemudian direfleksikan dan dianalisis berdasarkan teori yang menunjang, yang kemudian dilaksanakan tindakan dilapangan. Kesimpulan yang diperoleh tidak dapat digeneralisasikan pada ruang lingkup yang lebih luas, karena untuk kondisi dan situasi yang berbeda hasilnya dapat berbeda. Penelitian ini dapat dijadikan model untuk memberikan rekomendasi pada situasi yang lain (Arifin Imron, $1990:$ 4). Jenis penelitian yang digunakan adalah penelitian berusaha untuk memahami makna peristiwa dari interaksi yang terjadi selama penelitian berlangsung.

\section{Model Penelitian}

Penelitian ini merupakan penelitian tindakan kelas, karena penelitian ini dilaksanakan sesuai dengan langkah - langkah pada penelitian tindakan yang meliputi penyusunan rencana, melaksanakan tindakan, mengobservasi, melakukan analisis dan refleksi terhadap hasil observasi dari hasil analisis dan refleksi dari setiap akhir kegiatan dilakukan tindakan perbaikan pada siklus yang berikutnya berdasarkan hasil analisis dan refleksi yang dibuat sebelumnya.

Pada model pembelajar yang digunakan dalam penelitian ini pembelajaran kemampuan menganyam menggunakan kain perca.

\section{Rancangan Penelitian}

Penelitian tindakan ini dilaksanakan dalam dua siklus kegiatan yaitu siklus 1 dan siklus 2. Masing masing siklus terdiri 4 tahap kegiatan yaitu :

1. Menyusun Rencana Tindakan

2. Melaksanakan Tindakan

3. Melakukan Observasi

4. Membuat Analisis dilanjutkan Refleksi

Pada penelitian ini yang melaksanakan kegiatan mengajar adalah Kepala Taman Kanak - Kanak bersama - sama dengan Guru kelompok B sekaligus sebagai observer.

1. Penyusunan Rencana Tindakan 1

Pada tahap ini Kepala Taman Kanak - kanak menyusun rencana 
Jurnal Warna : Jurnal Pendidikan Dan Pembelajaran Anak Usia dini. September 2017. Vol 02. No. 02

pembelajaran berdasarkan pokok bahasan dan tema yang akan diajarkan yaitu kemampuan menganyam menggunakan kain perca meliputi merumuskan tujuan pembelajaran, menyusun langkah $\quad-$ langkah pembelajaran, merencanakan alat peraga (media) apa yang sesuai pokok bahasan yang yang akan diajarkan dari bagaimana menggunakannya, serta menyusun alat evaluasi yang sesuai dengan tujuan.

\section{Pemberian Tindakan 2}

Guru melaksanakan pengajaran dengan menggunakan media kain perca sesuai dengan perencanaan yang telah disusun. Pada kegiatan awal pembelajaran guru melakukan kegiatan berbagi dan bertanya serta tanya jawab tentang warna - warna disekitar anak. Anak diberi tugas untuk menyentuh dan mengenal warna -warna yang telah disediakan, kemudian anak diminta menghubungkan warna dari tiap kain perca menjadi suatu karya seni. Dengan memberikan tugas - tugas diharapkan anak mendapat pemahaman tentang konsep kemampuan mengenal warna dari kain perca yang telah disediakan.

\section{Melakukan Observasi}

Pada waktu kegiatan pembelajaran berlangsung, pada taman kanak - kanak bersama Guru kelompok B melakukan observasi dan mencatat kejadian - kejadian selama kegiatan pembelajaran berlangsung yang nantinya dapat bermanfaat untuk mengambil keputusan apakah guru dapat menggunakan kalimat dengan tepat atau perlu diadakan. Apakah tugas - tugas dan pertanyaan yang diajukan guru suda mencerminkan pembelajaran kemampuan menganyam kain perca.

4. Pembuat Analisis dan Refleksi

Dari hasil observasi dilakukan analisis pada tindakan 1 kemudian dilanjutkan dengan refleksi. Berdasarkan hasil analisis dan refleksi yang dilakukan bersama - sama ini, direncanakan perbaikan dengan melakukan tindakan 2 terhadap permasalahan - permasalahan yang masih ada. Untuk mengetahui apakah guru dapat menyusun rencana pembelajaran menganyam dengan menggunakan kain perca dapat Anak TK Tunas Muda dilihat dari komponen - komponen yang terdapat pada rencana pembelajaran yang telah disusunnya.

\section{Peran dan Posisi dalam Penelitian}

Pada penelitian tindakan kelas, peneliti selaku guru memiliki peranan penting untuk memahami betul - betul tugas dalam menganyam kain perca anak dan mempersiapkan diri dalam penelitian yang dilakukan.

\section{Tahapan Interversi Tindakan}

1. Mencari dan mengumpulkan informasi atau data anak menjadi subjek dalam penelitian. Informasi 
Jurnal Warna : Jurnal Pendidikan Dan Pembelajaran Anak Usia dini. September 2017. Vol 02. No. 02

diperoleh dari hasil observasi langsung terhadap anak - anak sesuai dengan RPPH ( Lampiran 1 ). Berdasarkan observasi awal pada anak usia 5-6 tahun di TK Tunas Muda Kersik Kec. Marangkayu dapat diketahui Meningkatan Konsentrasi anak dengan kegiatan menganyam kain perca usia 5-6 tahun.

2. Mempersiapkan media atau alat yang akan digunakan selama penelitian yang terkait dengan pelaksanaan melalui permainan menganyam kain perca.

3. Membuat evaluasi hasil atau penilian dari anyaman pada anak

\section{Hasil Intervensi Tindakan}

Hasil Intervensi tindakan yang diharapkan pada penelitian tindakan kelas ini, yaitu setelah anak melakukan kegiatan pembelajaran menganyam kain perca.

\section{Data dan Sumber Data}

Data

Data yang digunakan terkait dengan meningkatkan konsentrasi dengan kegiatan menganyam kain perca pada anak usia 5-6 tahun melalui kegiatan menganyam kain perca adalah data yang menggambarkan keberhasilan selama penelitian berlangsung. Data dalam penelitian ini adalah data kualitatif diperoleh data dengan mendeskripsikan peningkatan anak selama kegiatan menganyam kain perca dan kuantitatif merupakan data berupa pemberian skor pada asesmen awal dan asesmen akhir.

Sumber Data

Sumber data dalam penelitian tindakan kelas ini adalah hasil kegiatan menganyam kain perca pada anak usia 5-6 tahun TK Tunas Muda Kersik Kec. Marangkayu. Secara garis besar jenis data yang diperlukan dalam penelitian ini ada dua macam yaitu :

a. Sumber data primer yaitu anak Usia 5-6 Tahun yaitu berupa foto - foto kegiatan pembelajaran dan pengamatan dari guru sebagai observasi. (Lampiran2).

b. Sumber data sekunder yaitu data pendukung yang diperoleh dari informasi luar seperti kepustakaan.

Instrumen Pengumpulan Data yang Digunakan

Instrumen pengumpulan data dalam pelaksanaan tindakan kelas ini adalah observasi, catatan lapangan dan dokumentasi.

\section{Teknik Pengumpulan Data}

Teknik Pengumpulan data yang digunakan adalah observasi terstruktur yaitu :

1. Kisi - Kisi Instrumen Konsentrasi anak

a). Definisi Konseptual

Konsentrasi adalah kemampuan anak membuat kombinasi baru berdasarkan data, informasi atau 
Jurnal Warna : Jurnal Pendidikan Dan Pembelajaran Anak Usia dini. September 2017. Vol 02. No. 02

unsur-unsur yang ada. Kedua konsentrasi adalah kemampuan anak berdasarkan data atau informasi yang tersedia yang menemukan banyak kemungkinan jawaban terhadap masalah, dimana penekanan pada kreatifitas keragaman dan ketepat gunaan jawaban. Ketiga secara operasional konsentrasi dapat dirumuskan sebagai kemampuan yang mencerminkan kelancaran keluwesan (memperkaya, merinci, mengembangkan suatu gagasan).

b). Definisi Oprasional

Peningkatan kreativitas anak melalui kegiatan menganyam kain perca dapat dilihat dari perolehan skor setelah mengisi instrumen yang bertujuan untuk mengukur kemampuan anak dalam menganyam kain perca. Untuk menentukan keberhasilan dan keefektifan penelitian ini, maka dirumuskan indikator kinerja yang digunakan sebagai acuan keberhasilan. Adapun keberhasilan penelitian ini adalah diharapkan kemampuan menganyam kain perca pada anak melalui metode kegiatan menganyam kain perca mengalami peningkatan $75 \%$.

2. Jenis Instrumen

Teknik pengumpulan data yang dilakukan pada penelitian ini adalah metode observasi, dan dokumentasi.

a. Observasi

Observasi dilakukan sendiri, didalam maupun diluar kelas, yang dijadikan sebagai subyek penelitian, untuk mendapatkan peningkatan.

b. Catatan Lapangan

Disini peneliti mencatat seluruh kegiatan yang dilakukan dalam pengumpulan data yang dianggap perlu dan mendukung kelancaran penelitian.

Lampiran 3)

c. Dokumentasi

Dokumentasi digunakan untuk memperoleh data sekolah dan nama anak usia 5-6 tahun pada TK. Tunas Muda Kersik Kec. Marangkayu serta foto proses tindakan penelitian.

\section{Analisis Data dan Interprestasi Hasil} Analisis

Analisis data yang digunakan bertujun untuk mengetahui pengaruh pemberian tindakan berupa permainan menganyam kain perca pada anak usia 5-6 tahun TK Tunas Muda Kersik Kec. Marangkayu, Analisa data menggunakan analisa kualitatif. Sebagaimana dikemukakan Miles dan Hubermen dalam Wiriatmadja yakni tahapan redukasi data, display data, dan kesimpulan vervikasi serta refleksi. 
Jurnal Warna : Jurnal Pendidikan Dan Pembelajaran Anak Usia dini. September 2017. Vol 02. No. 02

Rochiati Wiratmadja ( 2005 : 136 ).

Data kualitatif dipaparkan dengan

kalimat yang dipisah - pisahkan menurut katagori untuk memperoleh kesimpulan. Data kuantitatif dipaparkan melalui hasil perhitungan nilai hasil observasi, kriteria deskriptif presentase, yang dikelompokkan dalam 4 kategori, yaitu BB ( Belum Berkembang ), MB ( Mulai Berkembang ), BSH Berkembang Sesuai Harapan ), dan BSB ( Berkembang Sangat Baik ). Kriteria Penilaian mengacu pada kurikulum 2010.

Tabel 1. Kriteria Deskriptif Presentase

\begin{tabular}{|c|c|c|}
\hline NO & Presentase & $\begin{array}{c}\text { Kriteria } \\
\text { Presentase }\end{array}$ \\
\hline 1 & $75-100 \%$ & $\begin{array}{c}\text { Mampu Sesuai } \\
\text { Harapan }\end{array}$ \\
\hline 2 & $50-75 \%$ & Mampu \\
\hline 3 & $25-50 \%$ & Mulai Mampu \\
\hline 4 & $0-25 \%$ & Belum Mampu \\
\hline
\end{tabular}

Keterangan penilian untuk anak

Adapun keterangan penilian untuk anak yang digunakan adalah sebagai berikut :

1. BM : Anak belum mampu menganyam menggunakan kain perca

2. MM : Anak mulai mampu menganyam menggunakan kain perca

3. M : Anak mampu menganyam menggunakan kain perca

4. MSH : Anak mampu menganyam menggunakan kain perca sesuai dengan harapan

\section{TEMUAN DAN PEMBAHASAN}

\section{Temuan Penelitian}

Berdasarkan pengamatan saat pra tindakan diperoleh hasil sebagai berikut, pra tindakan dilaksanakan pada hari Selasa 18 September 2017, jumlah anak yang hadir 8 anak tetapi peneliti hanya meneliti 8 anak dari kelompok B TK Tunas Muda Desa Kersik Kec. Marangkayu. Suasana terlihat menyenangkan ketika kegiatan menganyam menggunakan kain perca berlangsung, hal ini dikarenakan anak anak tertarik pada media yang digunakan yaitu dengan menggunakan kain perca untuk kegiatan menganyam. Anak - anak tertarik dengan sesuatu yang baru dan pembelajaran dengan menggunakan kain perca merupakan media yang baru bagi anak. Ketertarikan anak dapat diketahui ketika mereka berbisik - bisik sambil menunjuk kain perca, namun hasil observasi ketepatan anak dalam memegang bahan kain perca anak - anak adalah 4 anak atau 50\% belum mampu, 2 anak atau $26 \%$ mulai mampu, 2 anak atau 25\% mampu. Aspek kreativitas dalam menganyam kain perca 6 anak atau $75 \%$ belum mampu, 2 anak atau $25 \%$ maulai mampu. Aspek kecepatan anak dalam menganyam dalam menyelesaikan tugas 3 anak atau 37\% belum mampu, 3 anak atau $37 \%$ mulai mampu dan 2 anak atau 25\% mampu. Aspek kerapian hasil kerja 
Jurnal Warna : Jurnal Pendidikan Dan Pembelajaran Anak Usia dini. September 2017. Vol 02. No. 02

anak dalam menganyam kain perca 4 anak atau $50 \%$ belum mampu, 3 anak atau $37 \%$ mulai mampu 1 anak atau $13 \%$ mampu.

Melihat dari hasil observasi pra tindakan dapat dilihat dari hasilnya yang masih kurang dari $\leq 75 \%$ keberhasilan ini menunjukkan bahwa anak didik masih kesulitan dalam mengikuti kegiatan. Dengan demikian, pada siklus I pertemuan kesatu perlu adanya motivasi untuk mencapai keberhasilan.

Tabel 2. Hasil Observasi Pra Tindakan

\begin{tabular}{|c|c|c|c|c|c|c|}
\hline \multirow{3}{*}{ No } & \multirow{3}{*}{$\begin{array}{c}\text { Aspek } \\
\text { Penilaian }\end{array}$} & \multicolumn{4}{|c|}{ Hasil Penilaian } & \multirow{3}{*}{$\begin{array}{c}\text { Juml } \\
\text { ah }\end{array}$} \\
\hline & & 4 & 3 & 2 & 1 & \\
\hline & & $\%$ & $\%$ & $\%$ & $\%$ & \\
\hline \multirow[b]{2}{*}{1} & \multirow{2}{*}{$\begin{array}{l}\text { Ketepatan } \\
\text { anak dalam } \\
\text { memegang } \\
\text { kain perca }\end{array}$} & 0 & 2 & 2 & 4 & \multirow[b]{2}{*}{50} \\
\hline & & 0 & 25 & 25 & 50 & \\
\hline \multirow[b]{2}{*}{2} & \multirow{2}{*}{$\begin{array}{l}\text { Kreativitas } \\
\text { anak dalam } \\
\text { menganyam } \\
\text { kain perca }\end{array}$} & 0 & 0 & 2 & 6 & \multirow[b]{2}{*}{50} \\
\hline & & 0 & 0 & 50 & 50 & \\
\hline \multirow[b]{2}{*}{3} & \multirow{2}{*}{$\begin{array}{l}\text { Kecepatan } \\
\text { anak dalam } \\
\text { menyelesaika } \\
n \text { tugas }\end{array}$} & 0 & 2 & 3 & 3 & \multirow[b]{2}{*}{63} \\
\hline & & 0 & 26 & 37 & 37 & \\
\hline \multirow[b]{2}{*}{4} & \multirow{2}{*}{$\begin{array}{l}\text { Kerapian } \\
\text { hasil kerja } \\
\text { anak dalam } \\
\text { menganyam } \\
\text { kain perca }\end{array}$} & 0 & 1 & 3 & 4 & \multirow[b]{2}{*}{50} \\
\hline & & 0 & 13 & 37 & 50 & \\
\hline \multicolumn{2}{|c|}{$\begin{array}{c}\text { Total Kemampuan } \\
\text { Anak }\end{array}$} & 0 & 5 & - & - & 53 \\
\hline
\end{tabular}

Tabel 3. Keterangan Tentang Presentase

\begin{tabular}{|c|c|c|c|}
\hline No & $\begin{array}{c}\text { Rentang } \\
\text { Presentasi }\end{array}$ & $\begin{array}{c}\text { Krite } \\
\text { ria }\end{array}$ & Kategori \\
\hline 1 & $80<100$ & 4 & $\begin{array}{c}\text { Mampu Sesuai } \\
\text { Harapan }\end{array}$ \\
\hline 2 & $55<80$ & 3 & Mampu \\
\hline 3 & $35<60$ & 2 & Mulai Mampu \\
\hline 4 & $0<40$ & 1 & Belum Mampu \\
\hline
\end{tabular}

\section{Hasil Pelaksanaan Penelitian Tindakan Kelas Siklus 1 Hasil Pelaksanaan Siklus 1}

Untuk meningkatkan keterampilan motorik halus melalui kegiatan menganyam kain perca di TK Tunas Muda Desa Kersik Kec. Marangkayu pada tema : Diriku , subtema : ciri-ciri tubuh dan anggota tubuh adalah hasil dari pengamatan kegiatan pembelajaran menganyam ketepatan anak dalam memegang bahan kain perca anak - anak adalah 3 anak atau $37 \%$ belum mampu, 3 anak atau $37 \%$ mulai mampu dan 2 anak atau $25 \%$ mampu. Aspek kreativitas dalam menganyam kain perca 3 anak atau $37 \%$ belum mampu, 5 anak atau $62 \%$ maulai mampu. Aspek kecepatan anak dalam menganyam dalam menyelesaikan tugas 3 anak atau 37\% belum mampu, 3 anak atau 37\% mulai mampu dan 2 anak atau 25\% Mampu. Dan Aspek kerapian hasil kerja anak dalam menganyam kain perca 3 anak atau 37\% belum mampu, 3 anak atau 37\% Mulai Mampu, 2 anak atau $25 \%$ mampu.

Beberapa kendala yang perlu dicari solusi dan ditingkatkan yaitu :

1. Banyak anak yang masih bingung saat menganyam.

2. Anak yang menangis karena belum bisa menganyam menggunakan kain perca.

3. Kain perca yang digunakan dalam kegiatan menganyam merupakan alat baru bagi anak sehingga anak kesulitan dalam menganyam. 
4. Anak berebut saat mengambil anyaman yang ada di wadah.

5. Kain perca yang digunakan untuk menganyam rusak sehingga anak kesulitan untuk menganyam.

Melihat dari hasil observasi siklus

I Pertemuan ketiga dapat dilihat dari hasilnya yang masih kurang dari $\leq 75 \%$ keberhasilan. Ini menunjukkan bahwa anak didik masih kesulitan dalam mengikuti atau anak belum optimal dan belum mencapai indikator keberhasilan sebesar $75 \%$. Dengan demikian pada pertemuan selanjutnya dibutuhkan motivasi yang mendukung seperti alat peraga yang lebih menarik. Oleh karena itu peneliti akan melanjutkan pada Siklus II.

Anak sesuai target adalah mendapatkan nilai observasi 3 (Mampu) dan 4 (Mampu Sesuai Harapan). Ada siswa yang mengalami peningkatan. Untuk itu lebih jelas hasil observasi kegiatan anak didik pada siklus I hasil kesimpulan dapat dilihat pada tabel berikut :

Tabel 4. Rekapitulasi Keberhasilan Siklus I

\begin{tabular}{|c|c|c|c|c|c|}
\hline \multirow[b]{2}{*}{$\begin{array}{c}\text { Aspek } \\
\text { Penilaian }\end{array}$} & \multirow[b]{2}{*}{$\begin{array}{l}\text { Penil } \\
\text { aian }\end{array}$} & \multicolumn{4}{|c|}{ Kategori Penilaian } \\
\hline & & PI & PII & $\begin{array}{c}\text { PII } \\
\text { I }\end{array}$ & $\%$ \\
\hline $\begin{array}{c}\text { Aspek } \\
\text { Ketepatan }\end{array}$ & 1 & 50 & 50 & 75 & 3 \\
\hline $\begin{array}{c}\text { Aspek } \\
\text { Kreativitas }\end{array}$ & 2 & 62 & 62 & 87 & 3 \\
\hline $\begin{array}{c}\text { Aspek } \\
\text { Kecepatan }\end{array}$ & 3 & 37 & 62 & 62 & 3 \\
\hline $\begin{array}{c}\text { Aspek } \\
\text { Kerapian }\end{array}$ & 4 & 38 & 75 & 62 & 3 \\
\hline \multicolumn{2}{|c|}{$\begin{array}{c}\text { Total hasil } \\
\text { kemampuan anak }\end{array}$} & 48 & 62 & 71 & $\begin{array}{l}6 \\
0\end{array}$ \\
\hline
\end{tabular}

(Sumber data : Hasil Penelitian pada TK. Tunas Muda Desa Kersik Kec. Marangkayu tahun 2017 :

Tabel 5. Keterangan Rentang Presentase

\begin{tabular}{|c|c|c|c|}
\hline No & $\begin{array}{c}\text { Rentang } \\
\text { Presentasi }\end{array}$ & Kriteria & Kategori \\
\hline 1 & $80<100$ & 4 & $\begin{array}{c}\text { Mampu Sesuai } \\
\text { Harapan }\end{array}$ \\
\hline 2 & $55<80$ & 3 & Mampu \\
\hline 3 & $35<60$ & 2 & Mulai Mampu \\
\hline 4 & $0<40$ & 1 & Belum Mampu \\
\hline
\end{tabular}

Berdasarkan tabel di atas, siklus I dalam 3 kali pertemuan rata-rata anak 12,\% Mampu, rata-rata anak 40\% Mulai Mampu, rata-rata anak $46 \%$ Belum Mampu. Observasi siklus I pertemuan ketiga dapat dilihat hasilnya masih kurang dari 75\% keberhasilan dan dari 4 indikator didapatkan rata-rata hanya $40 \%$. Ini menunjukkan bahwa sebagaian anak masih kesulitan dalam mengikuti kegiatan. Pertemuan selanjutnya dibutuhkan motivasi yang lebih mendukung seperti alat peraga yang menarik bagi anak. Kegiatan dilanjutkan ke siklus II.

Beberapa kendala yang perlu dicari solusi dan ditingkatkan yaitu :

a. Banyak anak yang masih bingung saat menganyam

b. Anak yang menagis karena belum bisa menganyam dengan benar

c. Kain perca yang digunakan saat menganyam kurang formal bagi anak

d. Kain perca yang digunakan untuk menganyam kurang diminati anak 
Dari beberapa kendala yang muncul maka peneliti dan guru berdiskusi serta mencari solusi agar kegiatan pembelajaran berikutnya dapat berjalan dengan lancar dan dapat meningkatkan keterampilan motorik halus dalam kegiatan menganyam menggunakan kain perca. Solusi dari beberapa kendala tersebut yaitu:

a. Langkah-langkah pertama dalam kegiatan menganyam lebih diperjelas sehingga anak tidak bingung. Anak disuruh mengikuti langkah seperti saat pertama memulai menganyam menggunakan kain perca.

b. Guru memberikan kalimat positif kepada anak seperti "kamu bisa, ayo coba lagi”, agar anak tidak mudah putus asa dan mau mencoba. Langkah awal adalah guru membantu anak menganyam menggunakan kain perca untuk kemudian anak melakukan sendiri.

c. Peneliti menambah jumlah wadah yang tersedia untuk anak menjadi 2 anak mendapatkan satu wadah.

d. Peneliti memberikan contoh kepada anak sebelum menyuru anak untuk menganyam.

\section{Hasil Pelaksanaan Siklus II}

Melihat dari hasil observasi siklus II Pertemuan I,II dan III dapat dilihat dari hasilnya yang sesuai $75 \%$ keberhasilan. Ini menunjukkan bahwa anak didik sudah dapat mengikuti kegiatan dengan baik dan peneliti ini dinyatakan berhasil. Anak sesuai target adalah mendapatkan nilai observasi 3 (Mampu) dan 4 (Mampu Sekali). Ada siswa yang mengalami peningkatan. Untuk itu lebih jelas hasil observasi kegiatan anak didik pada siklus II hasil kesimpulan dapat dilihat pada tabel berikut :

Tabel 6. Rekapitulasi Keberhasilan Siklus II

\begin{tabular}{|c|c|c|c|c|c|}
\hline & & \multicolumn{4}{|c|}{ Kategori Penilaian } \\
\cline { 3 - 6 } $\begin{array}{c}\text { Aspek } \\
\text { Penilaian }\end{array}$ & $\begin{array}{c}\text { Penil } \\
\text { aian }\end{array}$ & PI & PII & PIII & $\%$ \\
\hline $\begin{array}{c}\text { Aspek } \\
\text { Ketepatan }\end{array}$ & 1 & 75 & 87 & 87 & 3 \\
\hline $\begin{array}{c}\text { Aspek } \\
\text { Kreativitas }\end{array}$ & 2 & 62 & 75 & 100 & 3 \\
\hline $\begin{array}{c}\text { Aspek } \\
\text { Kecepatan }\end{array}$ & 3 & 62 & 62 & 100 & 3 \\
\hline $\begin{array}{c}\text { Aspek } \\
\text { Kerapian }\end{array}$ & 4 & 82 & 62 & 100 & 3 \\
\hline $\begin{array}{c}\text { Total hasil } \\
\text { kemampuan anak }\end{array}$ & 70 & 71 & 96 & 79 \\
\hline
\end{tabular}

(Sumber data : Hasil Penelitian pada TK. Tunas Muda Desa Kersik Kec. Marangkayu tahun 2017 :

Tabel 7. Keterangan Rentang Presentase

\begin{tabular}{|c|c|c|c|}
\hline No & $\begin{array}{c}\text { Rentang } \\
\text { Presentasi }\end{array}$ & Kriteria & Kategori \\
\hline 1 & $80<100$ & 4 & $\begin{array}{c}\text { Mampu Sesuai } \\
\text { Harapan }\end{array}$ \\
\hline 2 & $55<80$ & 3 & Mampu \\
\hline 3 & $35<60$ & 2 & Mulai Mampu \\
\hline 4 & $0<40$ & 1 & Belum Mampu \\
\hline
\end{tabular}

Tabel diatas menunjukkan hasil observasi tindakan Siklus II di Tk. Tunas Muda Desa Kersik Kec. Marangkayu. Hasil tindakan Siklus II mengalami peningkatan, ada sebanyak 8 anak atau semua anak mendapat kriteria Mampu Sesuai Harapan. Hasil observasi memperoleh presentase rata-rata $75 \%$ pada Siklus II Pertemuan Ketiga dan 
Jurnal Warna : Jurnal Pendidikan Dan Pembelajaran Anak Usia dini. September 2017. Vol 02. No. 02

memenuhi indikator keberhasilan maka peneliti tidak dilanjutkan.

Telah terjadi peningkatan pada siklus ini dikarenakan penambahan kain perca sehingga anak lebih muda menganyam menggunakan kain perca. Selain itu anak dalam aspek Ketepatan, anak menjadi lebih cepat yaitu menyelesaikan anyaman sebelum pembelajaran berakhir. Dari hasil observasi Siklus II menunjukkan konsentrasi anak mengalami peningkatan yang signifikan. Peningkatan yang terjadi telah mencapai indikator keberhasilan, yaitu sebesar $75 \%$.

Oleh karena itu upaya peningkatan konsentrasi anak kegiatan menganyam di kelas B TK. Tunas Muda Desa Kersik Kec. Marangkayu tidak perlu dilanjutkan dan cukup dihentikan di Siklus II.

\section{Pembahasan Temuan Penelitian}

Penelitian yang dilakukan merupakan penelitian tindakan kelas yang terdiri dari II Siklus yang setiap siklus terdiri dari 3 kali pertemuan. Langkah-langkah setiap siklus yaitu perencanaan, pelaksanaan/ observasi dan refleksi. Siklus II merupakan langkah yang diambil untuk memperbaiki Siklus I sehingga dapat diperoleh indikator keberhasilan sebesar $75 \%$. Setiap permasalahan yang muncul diperbaiki sehingga mencapai target yang diharapkan. Hasil yang diperoleh menggunakan lembar observasi berupa ceklist $(\sqrt{ })$ dan hasilnya untuk mengetahui peningkatan konsentrasi anak disetiap pertemuan. Lembar observasi ini untuk mengamati penigkatan konsentrasi anak kelas B.

Konsentrasi dapat dikembangkan melalui berbagai kegiatan seperti membentuk atau memanipulasi dari (kain perca), mewarnai, menempel, memotong, menggunting, menganyam menggunakan kain perca. Menganyam adalah kegiatan yang dilakukan dengan menyusun kain perca selang seling, mengangkat kain perca yang harus diangkat dan kain perca yang tidak diangkat. Selain itu menganyam dapat menigkatkan konsentrasi anak, menganyam juga dapat menigkatkan perhatian dan kreativitas anak. Peneliti memilih menganyam menggunakan kain perca karena kain perca mudah didapatkan sehingga memungkinkan berkerasi menggunakan apa saja yang diinginkan kain perca yang sifatnya mudah dibentuk, lunak dan elastis dapat digunakan untuk macam-macam kerajinan. Selain itu kain perca tidak beracun, bisa diwarnai, anyaman yang dihasilkan juga bagus dan rapi. Dan pada saat pembelajaran berlangsung pendidik dapat membentuk kain perca yang disesuaikan dengan tema pada hari 
Jurnal Warna : Jurnal Pendidikan Dan Pembelajaran Anak Usia dini. September 2017. Vol 02. No. 02

itu sehingga tujuan pembelajaran dapat tercapai (Nanang Subarnas, 2006:73).

\section{Berdasarkan observasi}

pratindakan yang dilakukan oleh peneliti meningkatkan kosentrasi anak dalam hal kegiatan menganyam menggunakan kain perca pada TK. Tunas Muda Desa Kersik Ke. Marangkayu masih rendah. Hal ini diperoleh karena anak belum dapat menyelesaikan kegiatan sebelum pembelajaran berakhir dan belum dapat menganyam. Rendahnya keterampilan tersebut karena pembelajaran hanya berpaku pada majalah atau LKA. Alat permainan edukatif kurang beragam atau bervariasi, pembelajaran yang monoton, belum digunakan media dari bahan kain perca untuk kegiatan menganyam. Bertumpuh pada data tersebut, meningkatkan konsentrasi anak melalui kegiatan menganyam menggunakan kain perca perlu ditingkatkan. Peneliti ini sesuai dengan rencana yang telah dibuat oleh peneliti dan guru kelas. Pada setiap akhir tindakan ada diskusi terkait dengan hasil pengamatan yang dilakukan. Setelah dilakukan pengamatan kemudian direfleksikan untuk tindak selanjutnya kemudian ditarik kesimpulan. Refleksi pada Siklus I untuk diperbaiki di Siklus II antara lain : (1) penjelasan langkah-langkah menganyam menggunakan kain perca lebih diperjelas dengan guru mendemonstrasikan cara menganyam menggunakan kain perca sampai selesai, (2) kain perca lebih banyak, (3) lebih banyak varian warna dari kain perca, (4) mendampingi dan memotivasi anak, (5) menambah jumlah wadah yang tersedia agar anak tidak berebut saat mengambil anyaman.

Menurut Flood dan Laap (1981:350) kosentrasi anak saat belajar penting untuk mempertahankan minat dari ketertinggalan. Sumber motivasi umum adalah kepuasan peribadi yang diperoleh anak dari kegiatan tersebut, kemandirian dan gengsi yang diperoleh dari kelompok sebayanya, serta kompensasi terhadap perasaan kurang mampu dalam bidang lain khususnya dalam tugas sekolah. Guru dalam memotivasi anak dilakukan dengan cara memberikan pujian atas usahanya. Setelah dilakukan tindakan di Siklus II terjadi peningkatan lagi menjadi 8 atau 75\% dari 14 anak memperoleh kriterian Mampu Sesuai Harapan dan Mampu.

\section{PENUTUP}

\section{Kesimpulan}

Berdasarkan hasil penelitian yang telah dilakukan dapat disimpulkan bahwa melalui menganyam menggunakan kain perca dapat meningkatkan konsentrasi anak kelompok B di TK. Tunas Muda Desa Kersik Kec. Marangkayu. Pada Siklus I kegiatan menganyam menggunakan kain 
Jurnal Warna : Jurnal Pendidikan Dan Pembelajaran Anak Usia dini. September 2017. Vol 02. No. 02

perca dilakukan dengan menggunakan kain perca yang aman digunakan untuk anak-anak, sedangkan pada Siklus II dilakukan dengan mengumpulkan bemacam-macam warna kain perca dan dibentuk bulat dan setengah lingkaran. Langkah pembelajaran dalam penelitian ini yaitu guru menyampaikan anyaman dan kain perca dengan bentuk yang telah disesuaikan dengan tema, kemudian guru memberikan contoh cara menganyam menggunakan kain perca dan membagikan kain perca kepada anak.

\section{Saran}

Berdasarkan hasil dan kesimpulan penelitian yang telah diuraikan diatas maka dalam usaha untuk meningkatkan konsentrasi anak usia dini dengan menggunakan kain perca melalui kegiatan menganyam adanya srimansriman sebagai berikut :

1. Guru hendaknya melakukan pendekatan dan pendampingan untuk anak.

2. Mengoptimalkan pembelajaran menganyam menggunakan kain perca dengan berbagai bentuk sesuai tema agar anak tidak bosan dan antusias.

3. Untuk fakultas keguruan dan ilmu pendidikan khususnya pada Program Studi Pendidikan Guru Pendidikan Anak Usia Dini hendaknya dapat memberikan pengetahuan dasar mengenai pembelajaran konsep meningkatkan konsentrasi anak, agar kami dapat menjadi civitas akademika secara profesional tahun 2017 yang memiliki kompetensi, wawasan pengetahuan ilmu dan teknologi yang mendukung dalam pembangunan dalam pengembangan anak usia dini dan misi melaksanakan pendidikan dan pengajaran untuk menghasilkan lulusan yang profesional pada jenjang pendidikan-pendidikan pra sekolah dan sekolah dasar kelas awal, serta agar kami terbina, terlatih dan menjadi sumber daya manusia yang handal dalam rangka mengembagkan program-program pendidik anak usia dini, melaksanakan pengabdian kepada masyarakat.

\section{DAFTAR PUSTAKA}

Aisyah, Siti, dkk. 2008. Perkembangan

dan Konsep Dasar

Pengembangan Anak Usia

Dini.Jakarta: Universitas Terbuka.

Asrori, H. Mohammad. 2009. Penelitian Tindakan Kelas. Bandung : CV WacanaBuku Sumber Tentang Metode-Metode Baru. Jakarta : UI Press

Direktorat Pendidikan Anak Usia Dini Direktorat Jenderal Pendidikan

Fathurrohman, Pupuh dan Sobry Sutikno. 2010. Strategi Belajar 
Jurnal Warna : Jurnal Pendidikan Dan Pembelajaran Anak Usia dini. September 2017. Vol 02. No. 02

Mengajar. Bandung : PT

Refika Aditama

Fridani, Lara, dkk. 2009. Evaluasi

Perkembangan Anak Usia Dini.

Jakarta: Universitas Terbuka.

Hildayani, Rini, dkk. 2007. Psikologi Perkembangan Anak. Jakarta: Universitas Terbuka.

http://databermanfaat.blogspot.co.id/201 4/06/berbagi-makalahbertemakan-kain-perca.html

https://www.scribd.com/doc/207763424/ $\underline{\text { skripsi-kain-perca }}$

Milles, Mattew B dan A. Micheal Hubberman. 1992. Analisis Data Kualitataif :

Montolalu, B.E.F dkk. 2007. Bermain dan Permainan Anak. Jakarta : Universitas Terbuka

Nonformal dan Informal Kementerian Pendidikan Nasional Rahmat dkk, 1994. Kapita Selekta. Jakarta : Departemen Pendidikan dan Kebudayaan

Pamadhi, Hajar dan Evan Sukardi S. 2008. Seni Keterampilan Anak. Jakarta :

Permendiknas, 2010. Tentang Standar Pendidikan Anak Usia Dini. Jakarta :Prima

R. Moeslichatoen. 2004. Metode Pengajaran di Taman KanakKanak. Jakarta : PT Rineka Cipta Sugono, Dendy. 2008. KamRemaja Rosdakarya

Sukmadinata, Nana Syaodih. 2010. Metode Penelitian Pendidikan. Bandung : CV
Sumiati dan Asra. 2009. Metode pembelajaran. Bandung : $\mathrm{CV}$ Wacana Prima Universitar Terbuka Wacana Prima

Wiriaatmadja, Rochiati. 2009. Metode Penelitian Tindakan Kelas. Bandung : PT 